\title{
Virginia Master Gardeners Reveal Preferences in Broccoli Survey
}

\author{
Diane Relf ${ }^{1}$, Charles O'Dell' ${ }^{1}$ and Mosbah Kushad ${ }^{2}$ \\ Department of Horticulture, Virginia Polytechnic Institute and State \\ University, Blacksburg, VA 24061
}

Master Gardeners can be an excellent source of consumer preference information. To predict market potential for a large-headed, single-stalk, fresh broccoli product produced by Virginia growers, a survey of 1240 Virginia Master Gardeners was conducted, requesting information on purchasing preferences and consumption of broccoli. This was not a random market survey, but rather a survey aimed at high users of horticultural products and crops. The response rate was $>40 \%$ and most of the surveys were returned within 3 weeks. This indicates a survey topic with a very high level of consumer interest and a strong willingness on the part of Master Gardeners to participate in such research surveys. In addition, Master Gardeners on

Received for publication 23 Feb. 1989. The cost of publishing this paper was defrayed in part by the payment of page charges. Under postal regulations, this paper therefore must be hereby marked advertisement solely to indicate this fact.

'Associate Professor.

${ }^{2}$ Assistant Professor. the Virginia Tech campus compiled the survey results, saving the staff $\approx 10 \mathrm{hr}$ of work.

The purpose of the survey was to determine the market potential for a fresh, locally grown, specialized broccoli crop and to guide the extension specialists in developing that market. The survey was designed to determine consumers' broccoli-buying habits, whether broccoli stems were discarded or used for food, whether consumers would prefer to buy a large head with little stem or several small heads with large stems, and whether shrink-wrapping of broccoli, which retards deterioration (Forney et al., 1988), would affect consumer appeal.

Fresh broccoli was purchased by $97 \%$ of respondents, with $60 \%$ buying it year-round and the remainder buying principally locally grown broccoli in season. Slightly more than one-half of the respondents use only the heads $(53 \%)$, while $45 \%$ prepare and consume the stem if it is part of the package. However, an overwhelming $90 \%$ would buy a single large head of broccoli if it were available. A trend toward consumer acceptance of shrink- wrapped broccoli was indicated by a positive response of $55 \%$, while $35 \%$ indicated a desire to see this product in the store and then decide. Only $6 \%$ indicated decreased acceptance.

The results of this survey have led extension specialists to conclude that a "Virginia Style" broccoli with a large head and a small stem could provide expanded grower opportunities for the high-elevation western part of the state. Small-stem broccoli with large heads offers a simpler production system suitable either to the use of transplants or to direct seeding. A lower plant population : acre ratio would be used, since greater spacing would be needed to allow for the development of large heads, thus reducing costs while presumably increasing yields. The large heads will provide a high percentage of edible product, recently reported as an emerging consumer demand (American Vegetable Grower, 1988.)

This survey indicates that Master Gardeners are an excellent source of data on consumer preference within an existing group of high users of horticultural products. Their high return rate and prompt response make it possible to identify trends and provide guidance to extension and research projects.

\section{Literature Cited}

American Vegetable Grower. 1988. Broccoli boom creates demand for new types. September:4446.

Forney, CF., R.E. Rij, and S.R. Ross. 1988. Measurement of respiration rate of film-wrapped broccoli. HortScience 23:141. (Abstr.) 